\title{
Compositional Evolution OF CRETACEOUS CORDILlERAN VOLCANISM
}

\author{
SYDNEY M. ALLEN ${ }^{1 *}$, CIN-TY A. LEE ${ }^{1}$, AND DANIEL \\ MINISINI $^{2}$
}

'Rice University, Houston, TX 77005, USA

(*correspondence: sydney.m.allen@rice.edu)

${ }^{2}$ Shell Houston Technology Center, Houston, TX 77082, USA

Continental arc volcanism likely exhibits temporal variation

in composition and flux, but the timescale and nature of these

changes are poorly documented. Composition can affect

explosivity, amount of ash and volatiles, and the availability

of nutrients such as $\mathrm{Fe}, \mathrm{Si}$, and $\mathrm{P}$, thereby influencing

volcanic hazards, climate, and biological productivity. We

examine a sediment core from the Cretaceous Western

Interior Seaway, a distal backarc basin that records nearly 300

distinct eruptions between 90-97 Mya. The combination of

the many eruptions and their high-precision, astronomically

tuned age model applied by past studies allows us to construct an extraordinarily high temporal resolution record of composition in the Cretaceous Cordillera. As Si is mobile in the intense secondary processes involved in the transformation of ash into bentonite, we must reconstruct $\mathrm{SiO}_{2}$ from geochemical proxies such as the immobile element ratio Ti/Zr. Our compilations of modern continental arc data

from the Andes, Cascades, and Central America show that the relationship between Cordilleran $\mathrm{Ti} / \mathrm{Zr}$ and $\mathrm{SiO}_{2}$ is independent from location. Therefore, we can use this relationship to reconstruct ash $\mathrm{SiO}_{2}$ without knowing the precise source of the ash. We apply our reconstruction procedure to 46 bentonites to show that volcanic composition varied in a cyclic manner over timescales of approximately 1 Myr. As $\mathrm{SiO}_{2}$ has been linked to crustal thickness, these observations have important implications for changes in the transcrustal magmatic system. While it is unclear whether such changes over 1 Myr timescales are driven by tectonic or magmatic triggers, what is evident is that our approach affords unique perspectives towards understanding these processes driving Cordilleran volcanism. 